\title{
Struggling on the Home Front: The Personal, the Political, and Working-Class Women
}

\section{Citation}

Cohen, Lizabeth. 1996. Struggling on the home front: The personal, the political, and workingclass women. Radical History Review 64: 105-112.

\section{Published Version}

doi:10.1215/01636545-1996-64-105

\section{Permanent link}

http://nrs.harvard.edu/urn-3:HUL.InstRepos:4699749

\section{Terms of Use}

This article was downloaded from Harvard University's DASH repository, and is made available under the terms and conditions applicable to Other Posted Material, as set forth at http:// nrs.harvard.edu/urn-3:HUL.InstRepos:dash.current.terms-of-use\#LAA

\section{Share Your Story}

The Harvard community has made this article openly available.

Please share how this access benefits you. Submit a story.

Accessibility 


\section{Struggling on the Home Front: The Personal, the Political, and Working-Class Women}

\section{Lizabeth Cohen}

Dana Frank, Purchasing Power: Consumer Organizing, Gender, and the Seattle Labor Movement, 1919-1929. New York: Cambridge University Press, 1994. \$64.95 (cloth); $\$ 18.95$ (paper).

Joanne Meyerowitz, ed., Not June Cleaver: Women and Gender in Postwar America, 1945-1960. Philadelphia: Temple University Press, 1994. \$49.95 (cloth); \$19.95 (paper).

With all the progress that has been made in reconstructing the history of women's experience over the twentieth century, we know much more about the evolving political and social lives of middleclass women than of their working-class counterparts. The suffragist of the 1910s turned League of Women Voters' member in the 1920s, and the professional woman of the 1930s turned suburban housewife in the 1940s figure more into our conceptualizations of twentieth-century women's experience than their sisters who labored in factories or struggled to manage households on a male breadwinner's supposed "family wage." Fortunately, two recent booksDana Frank's Purchasing Power and Joanne Meyerowitz's edited collection Not June Cleaver-promise important new insights into the concerns of working-class women during the century's two postwar periods, 1919 to 1929 and 1945 to 1960 .

The coincidence of the two books also makes it possible to compare these two eras that, on the surface anyway, followed remarkably similar trajectories. Working-class Americans came out of both world wars highly unionized and determined to protect wartime gains in conversion economies, only to encounter state-supported employer backlashes against labor. Working women in both eras faced social pressure to leave wartime jobs for an idealized domes- 
ticity, constructed in large part around the new benefits and responsibilities of mass consumption. The 1920s and 1950s have, in fact, become the templates for "normalcy" in the twentieth century, periods assumed to have delivered economic prosperity and political calm following the traumas of war and labor unrest and preceding the tenser times of the 1930s and 1960s. These two books can help us determine the validity of these prevailing stereotypes for the lives of working-class Americans and begin to chart, particularly for women, how their experiences may have changed over those decades.

Both of these books have made pathbreaking contributions broader than the concern of this essay. Frank gives us the best analysis I've read of how the American Federation of Labor (AFL) went from enjoying the kind of broad-based radical strength it had in Seattle in 1919, to the top-heavy, conservative business unionism with which it greeted the Great Depression. She shows how downturns and shifts in Seattle's economy, the employers' open shop drive, political differences, and anti-Japanese racial tensions within the city's working class converged to leave the AFL a mere shell of what it had been, dependent on the sole organizing strategy of the union label. Frank makes another major contribution to labor history in arguing that organizing "at the point of consumption"--through cooperatives, boycotts, labor-owned businesses, and union label and shop-card campaigns-has been inseparable from organizing "at the point of production" in all periods of U.S. history, but particularly at this time in Seattle. Mobilizing unionists to wield their power at the marketplace as well as at the workplace, to "shop union," she claims, has long been an integral part of labor organization, despite historians' tendency to overlook it.

Meyerowitz likewise revises some standard assumptions of American historiography. The essays she has collected in this volume correct, or at least refine, the prevailing view initiated by Betty Friedan in The Feminine Mystique and perpetuated in historical studies like Elaine May's Homeward Bound: American Families in the Cold War Era, that most women in the post-World War II era conformed to the stereotype of the suburban, politically quiescent housewife. The essays in Meyerowitz's collection demonstrate that many women didn't fit because they were not white, middle-class, married, and suburban, and other women didn't fit even though they were. She argues that we must view the stereotype more critically as a construction that "women appropriated, transformed and challenged ... even as it was constructed" (2). ${ }^{1}$ Although my focus here 
on working-class women forces me to be selective about which essays in Meyerowitz's collection I will discuss, I should say that this volume is a rarity in including so many high-quality essays. I urge readers to read them all.

I turned to Frank's book hoping that her attention to "purchasing power," and focus on "consumer organizing, gender, and the Seattle labor movement" would illuminate a realm of political activity by working-class women heretofore overlooked, because labor historians have paid more attention to production than consumption. Given that women were responsible for $80-90$ percent of the shopping in working-class families, the explosion of consumer organizing in the immediate postwar period in Seattle promised to provide an ideal opportunity to examine the political activity of workingclass women.

I learned to my surprise, however, that much of the Seattle labor movement's consumer organizing-grocery cooperatives, boycotts of stores like the giant Bon Marché department store, labor-owned businesses, and union label campaigns-were promoted and supported by male unionists, particularly the craft-based trade unions. Women, both wage earners and the non-working wives of union members, resisted these consumer strategies as a kind of "speed up" that burdened them as the family's chief purchasers with greater inconvenience and expense. Consumer organizing, then, often pitted male waged labor seeking to punish employers who were "unfair" to unions against female unwaged labor resistant to further exploitation at the hands of their husbands and their husbands' unions. Aware that the shopping behavior of their wives was undermining the success of the consumer strategy, male unionists frequently tried to assert their patriarchal authority and discipline their wives, but with little success. Rather than showing consumption to be the weapon through which working-class women fought their class enemies, as one might have supposed, Frank's analysis presents it as the grounds for gender contestation within the working-class family.

The lack of enthusiasm among working-class women for consumer organizing in Seattle should not be construed as a sign of weak political commitment. Frank shows us wage-earning women committed to unionization, and working-class housewives joining them in campaigns to increase the state minimum wage for women, to free Tom Mooney and other political prisoners, to fight capital punishment, and to reduce judges' salaries. In short, working-class women-wage-earning or not--felt that politics at the point of consumption came too much at their own expense, and so they boy- 
cotted them rather than the merchants whom the Seattle Central Labor Council had targeted.

Male unionists continued to promote a labor politics unsympathetic to women into the 1920s. In the face of the open shop drive and economic depression, they argued against the employment of married women, laid off the Central Labor Council's organizer for women, and weakened the voice of female workers in the Seattle labor movement. We are left with an image of failed labor solidarity by the mid-1920s, due not only to the standard ethnic, racial and ideological differences among workers, but also to gender tensions within the working-class family, particularly between wage-earning men and their wives, whose "work" as household managers often went unappreciated.

The implication of these gender politics for the labor movement as an institution is clear. Frank's argument fits well with Elizabeth Faue's conclusion that over the course of the twentieth century the Minneapolis labor movement became increasingly male in orientation, moving farther and farther away from the community-based, gender-inclusive unionism of the nineteenth-century Knights of Labor. ${ }^{2}$ The implications of Frank's findings for the institution of the working-class family is less clear and deserves further investigation. Understanding the tensions within working-class families-between husbands and wives, between generations and genders of wageearners, between producers and consumers-as they tried to function as units of production and consumption is crucial to a deeper analysis of the lives of working-class women, as well as men. Labor history studies of female workers and occupations should continue, but we must give equal attention to working-class women's experiences within their families and communities. ${ }^{3}$ Only then will we move beyond a false dichotomy in historical investigation where middle-class women have family roles and community activities and working-class women only have jobs.

Several essays in Meyerowitz's fine collection can contribute to this discussion of the lives of working-class women as well as suggest how gender dynamics in working-class families may have evolved from the 1920s through the 1950s. Xiaolan Bao's "When Women Arrived: The Transformation of New York's Chinatown," shows how Chinese women, newcomers to Chinatown with changes in U.S. immigration policy in the postwar period, used jobs in the garment industry to strengthen their authority at home. Previously, the relatively small number of women in Chinatown worked in family laundries and other small businesses under the thumb of their 
husbands. Changes in the larger economy, the rise of laundry technology, and the growing availability of cheap, unskilled female labor helped Chinatown's garment industry thrive, and Chinese working-class women seized the opportunity to empower themselves financially to support what Bao calls the "mother-centered Chinese working-class family," which challenged the traditional male-dominated Chinese family of China and America.

Although Bao does not make the point, it strikes me that ChineseAmerican working-class families of the postwar era were beginning to look more like mainstream middle-class families, particularly in terms of the new emotional bonds between mothers and children and the increasing authority of women on the domestic front. Yet these new family interactions were possible due to Chinese women's growing independence as wage-laborers, rather than resulting from the domestic isolation of middle-class white women, suggesting the necessity of probing the distinctive class and ethnic contexts behind behavior that might on the surface seem similar. Moreover, the selfconfidence that Chinatown women gained from their domestic authority vis a vis men stimulated what Bao calls a "political awakening," culminating in a huge strike of women garment workers in 1982. Clearly, the outcomes of postwar women's empowerment in the home also differed by social group, reinforcing my argument that women's workplace behavior cannot be separated from their domestic and community lives.

Dorothy Sue Cobble expands on this interweaving of women's struggles at the workplace and the gender dynamics of their home lives in "Recapturing Working-Class Feminism: Union Women in the Postwar Era." Cobble argues that unions in the postwar era became vehicles for working-class women's feminist aspirationswhich reflected their own definitions of feminist equality and advancement, rather than those of middle-class women. She shows, for example, how female unionists pushed for equal pay and upgrading for jobs done by women, rather than demanding that women be given jobs traditionally filled by men. Justice and equality at the workplace did not have to be based on "sameness." Special treatment--such as protective legislation, paid maternity leaves, and childcare benefits-was not incompatible with demands for equal treatment on payday.

Cobble's essay concludes with an even bigger claim: that working-class feminists "bore the torch of gender equality and justice in the 1940 s and $1950 \mathrm{~s}^{\prime \prime}$ as the middle-class traditions of equal rights feminism went into hibernation until the 1960s (75). But were she to 
expand this ambitious work, she should consider deepening her analysis by following these working-class unionists home and probing how their family and community experiences shaped the character of their distinctive feminism at the workplace. Susan Rimby Leighow's essay on nurses in the postwar era, "An 'Obligation to Participate': Married Nurses' Labor Force Participation in the 1950s," reveals a similar mix of feminist assertiveness and feminine job requirements, such as part-time schedules and day care. Seeing working-class feminism in the context of marriage relations, childrearing responsibilities, and other aspects of working-class life would not only help define it as an ideology, but would also illuminate working-class womanhood of the 1950s in relationship to both middle class of that era and working class at earlier times.

The theme that a distinctive working-class version of $1950 \mathrm{~s}$ female domesticity had political effects in the larger world also comes through in Margaret Rose's essay, "Gender and Civic Activism in Mexican American Barrios in California: The Community Service Organization, 1947-1962." In her investigation of the Community Service Organization (CSO), which defined itself as a "self-help, civic action agency" devoted to improving living conditions, promoting education and welfare programs, and protecting human and civil rights, Rose finds that "the postwar cultural emphasis on home, family, and community had a less conservative meaning among Mexican-American activist women and men." (179)

Traditional female skills-clerical work, hostessing, cooking, neighborliness, teaching, and stretching and supplementing budgets-sustained the CSO, but also involved women in political work reaching far beyond the domestic realm. Women, for example, put their skills to work preparing noncitizens for citizenship examinations, registering new voters to elect Mexican-American representatives to city councils, protesting against locating dump sites in East Los Angeles, and lobbying for state old-age assistance for elderly noncitizens. Rose concludes that the CSO functioned as "an important bridge to the expanding options of the 1960s," when female CSO organizers got jobs in President Johnson's Great Society programs, in government agencies, and in labor organizing, bringing organizing techniques learned at the $\mathrm{CSO}$ to their new endeavors (194-95).

Finally, Ruth Feldstein's fascinating essay, "I Wanted the Whole World to See': Race, Gender, and Constructions of Motherhood in the Death of Emmett Till," adds another dimension to my claim that working-class women's political and family lives were intertwined 
in the 1950s, by exposing the extent to which public opinion judged women's public actions according to domestic ideals of "womanhood" and "motherhood." In 1955, Emmett Till, a fourteen-year-old African American from Chicago, was murdered by two white segregationists while he was visiting his relatives in Mississippi, because he allegedly whistled at Carolyn Bryant, the wife of one of the white men. During the course of the funeral and the trial, the most personal aspects of Mamie Till Bradley's mothering of her son Emmett became the subject of public scrutiny, encouraged not only by Bradley herself, the defense and prosecution, but also by the maledominated NAACP, who eventually rejected Bradley's claim to represent the case publicly on the authority of her motherhood.

During the trial, Bradley's motherhood was also pitted against that of Carolyn Bryant, the working-class, white, Southern woman who Emmett supposedly insulted, raising important questions about racialized definitions of the "good mother." Without going into the further complexities of Feldstein's argument, the point should be sufficiently clear that in the public discourse of the 1950s, working-class women's qualities of mothering followed them into the public arena, shaping their own involvement in-as well as the larger nation's struggle with-civil rights.

This review of new research on working-class women in the 1920 s and 1950s suggests that some important revisions are in order for our stereotypical images of the two postwar decades. Rather than dichotomizing between family and work/community, or private and public life, twentieth-century historians need to heed better the insights of scholars of nineteenth-century women and recognize the interconnections between what happened in the family and what occurred in the larger world. The personal was political for working-class women way before the 1960 s, particularly it seems in these eras of so-called quiescent "normalcy." In addition, this new work suggests that during periods generally known for women's domestic isolation, working-class women were involved in more public activity than has previously been assumed. Most evident, women participated in the labor movement during both the $1920 \mathrm{~s}$ and the 1950s, bringing to it their own version of feminist politics deeply rooted in the dynamics of their personal relations as wives, mothers, and single women.

Working-class women's involvement in the labor movement, moreover, shifted between the 1920s and 1950s, alerting us to important changes underway over the century. While women in the 1920s struggled as workers and wives with a hostile trade union move- 
ment, working-class women in the 1950 s were more likely to be employed themselves and active participants in unions responsive to their needs, as these women understood them. Here we might wonder what happened to the male dominated unionism identified by Frank and Faue; Cobble asserts that the increasing sex segregation of labor markets and labor unions by the 1950s ironically gave women more political autonomy in labor organizations. That public activity, furthermore, carried over into women's personal lives. Even among fairly recent immigrant women, such as the Chinese in New York and the Mexicans in Southern California, experience with the International Ladies' Garment Workers Union changed expectations for what were appropriate family and community roles.

The stereotype of women isolated in the domestic sphere during eras of "normalcy" must be viewed then, as Meyerowitz proposes, as a deliberate construction, intended to make female political passivity the norm. The important new work reviewed here has gone a long way in demonstrating how porous was the membrane separating private and public experience. When working-class women resisted a trade union consumer boycott as a "speed up" and then rejected the discipline of husbands who tried to enforce it, they were being politicized in no less significant ways than when they struggled against employers. How working-class women in the twentieth century mediated between the often competing pressures of their class and gender, complicated in many cases by racial and ethnic identities, is a story we are just beginning to understand. What is clear is that it is a story that must be located in the multiple settings in which women lived out their lives.

Notes

1. Betty Friedan, The Feminine Mystique (New York: Norton, 1963); Elaine Tyler May, Homeward Bound: American Families in the Cold War Era (New York: Basic Books, 1988).

2. Elizabeth Faue, Community of Suffering \& Struggle: Women, Men, and the Labor Mozement in Minneapolis, 1915-1945 (Chapel Hill: University of North Carolina Press, 1991).

3. Important studies of women workers in the twentieth century are Susan Porter Benson, Counter Cultures: Saleswomen, Managers, and Customers in American Department Stores, 1890-1940 (Urbana: University of Illinois Press, 1986); Dorothy Sue Cobble, Dishing It Out: Waitresses and Their Unions in the Twentieth Century (Urbana: University of Illinois Press, 1991); and Nancy F. Gabin, Feminism in the Labor Movement: Women and the United Auto Workers, 1935-1975 (Ithaca, NY: Cornell University Press, 1990). 